\title{
Improved $\beta$-galactosidase Secretion in Fresh Water Fungi through Cultural Optimization
}

\author{
Olufemi Emmanuel Bankefa ${ }^{1,2, *}$, Ruth Adefolakemi Gabriel-Ajobiewe ${ }^{1}$, \\ Hafiz Awofe Akinyele ${ }^{1}$, Seye Julius Oladeji ${ }^{1}$, \\ Ebenezar Ayodele Oke ${ }^{1}$ and Olanike Mercy Ilori ${ }^{1}$
}

${ }^{1}$ Department of Microbiology, Federal University Oye-Ekiti, Ekiti-State, Nigeria
${ }^{2}$ State Key Laboratory of Biotechnology, Akure, Ondo state, Nigeria

("Corresponding author's e-mail: femibankefa@gmail.com, olufemi.bankefa@fuoye.edu.ng)

Received: 30 September 2020, Revised: 12 May 2021, Accepted: 30 May 2021

\begin{abstract}
The wide range of applications of $\beta$-galactosidase has made it a candidate enzyme of study for improved yield. Most studies focused on expressing this enzyme in expressible vector(s) while sources of this enzyme are rarely investigated. Aquatic habitats harbor arrays of microorganisms that can participate in demineralization, nutrient restoration, circulation and hence confer significant properties on the habitats and significantly influence microbial interactions and metabolism. In view of this, aquatic fungal isolates were qualitatively and quantitatively screened for intracellular and extracellular $\beta$-galactosidase production. Four fungal isolates tagged SB01 and SC02 from stream identified as Aspergillus oryzae and Aspergillus niger and SC01 and SA01 from pond identified as A. oryzae and A. niger were studied. $\beta$ galactosidase gene was successfully amplified from the four isolates and their enzyme production levels were further studied. All the isolates showed considerably higher extracellular secretion than the intracellular synthesis on glucose-based medium. The production level was probed by xylose supplementation but surprisingly, the intracellular synthesis was higher than the extracellular secretion for all the isolates. In an attempt to boost the enzyme production, temperature was varied and $25{ }^{\circ} \mathrm{C}$ showed improved $\beta$-galactosidase synthesis and secretion than the $30{ }^{\circ} \mathrm{C}$. This study revealed these filamentous fungi as candidates for $\beta$-galactosidase production and broaden the understanding of harnessing microorganisms from an aquatic reservoir for bio-production, and more importantly, revealed the intracellular accumulation of the enzyme as a bottleneck for industrial production.
\end{abstract}

Keywords: $\beta$-galactosidase, Aspergillus niger, Aspergillus oryzae, Secretion, Synthesis

\section{Introduction}

$\beta$-galactosidase, also known as lactase is an enzyme that catalyzes the hydrolysis of terminal nonreducing $\beta$-D-galactose residues in $\beta$-D-galactosides or the transfer of galactosyl residue to saccharide acceptors to yield galacto-oligosaccharides. $\beta$-galactosidase has a wide range of application, from prevention of lactose crystallization in frozen and condensed milk products to reduction of water pollution caused by whey, increase sweetening properties of lactose [1], and hydrolysis of lactose that catalyzes trans-glycosylation reaction leading to formation ofdi-, tri-, or higher galacto-oligosaccharides (GOS) [2]. The cosmopolitan nature of this enzyme existing in; plants, animals and microorganisms [3,4] has instigated diverse studies. Although several microbial sources are of great technological interest as they offer various advantages over other available sources such as easy handling, relatively stable, higher multiplication rate and high production rate and yield [5].

The interest in commercial production of this enzyme has implicated a large number of microorganisms such as Aspergillus spp., Kluveromyces spp., Bifidobacterium spp., Lactobacillus spp., and Geuhomyces pullulan, among others as potential sources of this enzyme [6]; however, only Aspergillus niger, Aspergillus oryzae and Kluveromyces lactis are considered safe for food and industrialrelated applications. Although a novel organism with other benefits was screened and also identified in the production of the enzymes [7]. As important as this enzyme is, its commercial production is still being bottlenecked with poor activity and to alleviate this menace, heterologous expression of this enzyme in Escherichia coli, Saccharomyces cerevisae and Pichia pastoris microbial cell factories is 
being studied while microbial screening for enzyme production from natural habitats is also being considered [8].

Interestingly, microbial habitat influences the physiological and metabolic properties of an organism, with significant effect on the synthesis and properties of the product. For instance, environmental factors can affect microbial communities both in terms of structures and function [9], thereby determining the output of such microorganism upon selection. The aquatic environment harbors many microorganisms which participate in the decomposition of organic material, demineralization, restoring nutrients and influencing nutrient circulation within such environment, thereby conferring properties on such habitat and also influencing microbial functionality. In addition to this, microbial productivity depends largely on the environmental factors where microorganisms are found [10]. Therefore, the biodiversity and the physicochemical properties of aquatic environment depict a unique habitat for study. Furthermore, despite the multifunctional properties of $\beta$-galactosidase, there is still a concern of meeting consumers' need, which thus suggests that harnessing great potential of aquatic microbial community could be a panacea towards improved secretion of the enzyme. Thus, the present study is aimed at screening fungal isolates from aquatic community for $\beta$-galactosidase production and optimized the cultural conditions for improving the secretion efficiency.

\section{Materials and methods}

\section{Water collection, isolation and identification of fungal isolates}

Both stream and pond water samples from Oye-Ekiti,south-western part of Nigeria, were collected into a sterile glass tubes aseptically and tagged SA and SB, respectively. The samples were taken from Oye-Ekiti to test-proof the efficacy of these fungi in secreting the enzyme. The water samples were diluted with sterile double deionized water and $1 \mathrm{~mL}$ of the diluent $3\left(10^{-3}\right)$ was pour plated into $39 \mathrm{~g} / \mathrm{L}$ PDA containing medium supplemented with $100 \mathrm{mg} / \mathrm{mL}$ chloramphenicol antibiotics. Plates were allowed to firmly set prior to incubation at $25{ }^{\circ} \mathrm{C}$ for 7 days. Mixed spores from the plates were distinctively and morphologically sorted, and thereafter sub-cultured to obtain pure culture. For identification, cotton blue lactophenol staining was performed as described in medical microbiology guide [11].

\section{Fungal genomic DNA extraction}

The genomic DNA was extracted from 5 days old fungal cultures cultivated in broth following the method described by Burik et al. [12]. Fungal mass culture was harvested by 5,000 rpm centrifugation. The broth was carefully separated from the mass and the mass was suspended in a tube containing 60 - 80 mg sterile glass beads (425 - $600 \mu \mathrm{M}$, Sigma) and lysis buffer (100 mM Tris $\mathrm{HCl}$ [pH 8.0$], 50 \mathrm{mM}$ EDTA, $3 \%$ SDS). The plates were thereafter homogenized on a table top homogenizer with intermittent cooling on ice by 10 disruption cycle processes with 1-min disruption and 1-min cooling single cycle. The homogenates were subsequently subjected to $12,000 \mathrm{rpm}$ for $10 \mathrm{~min}$ in order to aspirate the supernatant. $10 \mathrm{mg} / \mathrm{mL}$ RNase A was added to the supernatant and incubated at $37{ }^{\circ} \mathrm{C}$ for $15 \mathrm{~min}$. Phenol, chloroform and isopropyl alcohol were afterward added and inverted for proper mixing before centrifugation at 13,000 rpm for $10 \mathrm{~min}$. The upper layer was pipetted into another new micro centrifuge tube and equal volume of absolute ethanol was added and precipitated for $1 \mathrm{~h}$ at $20{ }^{\circ} \mathrm{C}$. Upon precipitation, the tubes were subjected to $12,000 \mathrm{rpm}$ for $10 \mathrm{~min}$ to obtain the DNA as pellet and $70 \%$ ethanol was added and allowed to stay for $2 \mathrm{~min}$ before centrifugation at 12,000 rpm for $5 \mathrm{~min}$. The DNA was allowed to air dry for $5 \mathrm{~min}$ at $25{ }^{\circ} \mathrm{C}$ before dissolving in $1 \times \mathrm{TE}$ buffer. The quantity of the extracted gDNA was determined by measuring the absorbance at 260 and $280 \mathrm{~nm}$ using Thermo Scientific Nano Drop spectrophotometer.

\section{Molecular identification and sequencing}

Both ITS-1 and ITS-4 primer pairs (details in Table 1) were used for molecular identification of the organisms tested positive to $\beta$-galactosidase. A $25 \mu \mathrm{L}$ High fidelity PCR amplification system containing $5 \mu \mathrm{L} 5 \mathrm{X}$ buffer, $2 \mu \mathrm{L}$ DNTP, $15 \mu \mathrm{L} \mathrm{H} \mathrm{H}_{2} \mathrm{O}, 1 \mu \mathrm{L}$ gDNA, $0.5 \mu \mathrm{L}$ PrimeSTAR and $1 \mu \mathrm{L}$ each of the primers. The 35 cycles of amplification was carried out in a PCR mastercycler (Eppendorf) as follows: $94{ }^{\circ} \mathrm{C}$ for 1 min; annealing at $55.5^{\circ} \mathrm{C}$ for $2 \mathrm{~min}$ and extension at $72{ }^{\circ} \mathrm{C}$ for $2 \mathrm{~min}$; and a final extension step at $72{ }^{\circ} \mathrm{C}$ for $10 \mathrm{~min}$. The PCR products were thereafter sent for sequencing. The sequencing data were mapped into the GeneBank (https://www.ncbi.nlm.nih.gov/genbank) for their accession numbers. 


\section{Amplification of $\beta$-galactosidasegene from gDNA}

The gDNA was used as template for amplification of $\beta$-galactosidase gene. For $A$. oryzae and $A$. Nigerfungal isolates, galAor-F/galAor-R and galAni-F/galAni-R primer pairs (Table 1) were used for amplification respectively. A $50 \mu \mathrm{L}$ High fidelity PCR amplification system containing $10 \mu \mathrm{L} 5 \mathrm{X}$ buffer, $4 \mu \mathrm{L}$ DNTP, $32 \mu \mathrm{L} \mathrm{H} \mathrm{H}_{2} \mathrm{O}, 1.5 \mu \mathrm{L}$ gDNA, $0.5 \mu \mathrm{L}$ PrimeSTAR and $1 \mu \mathrm{L}$ each of the primers with $45-68{ }^{\circ} \mathrm{C}$ annealing temperature, was adopted.

Table 1 List of primers.

\begin{tabular}{ll}
\hline Primers & Oligonucleotides \\
\hline ITS-1 & GTCGTAACAAGGTTTCCGTAGGTG \\
ITS-4 & TCCTCCGCTTATTGATATGC \\
galAor-F & CTCGAGAAAAGATCCATCAAGCATCGTCTCAATG \\
galAor-R & GCGGCCGCTTAGTATGCTCCCTTCCGCTGC \\
galAni-F & CTCCTAGGGGAATTGAAGCAAGCCTCCTG \\
galAni-R & GCGGCCGCTCACTGCATAGAAGCATAATC \\
\hline Synthesized by Beijing Rubio BiotechCo., Ltd [13]
\end{tabular}

\section{Inoculum preparation}

Inoculum preparation was done in $250 \mathrm{~mL}$ Erlenmeyer flasks containing $100 \mathrm{~mL}$ medium per liter:

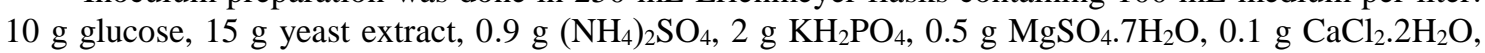
$0.5 \mathrm{~g} \mathrm{KCl}, 0.5 \mathrm{~g}$ thiamine in citrate phosphate at $5.0 \mathrm{pH}$. The medium was inoculated with bored fungus Potato Dextrose Agar (PDA) of $7 \mathrm{~mm}$ diameter and incubated at $25^{\circ} \mathrm{C}$ and $100 \mathrm{rpm}$.

\section{Shake flask fermentation}

An aliquot from inoculum was transferred into $25 \mathrm{~mL}$ of medium (same composition as that of inoculum preparation) in one batch and in the other batch substituting glucose with xylose with an initial 2 cell density at $600 \mathrm{~nm}$ Optical Density $\left(\mathrm{OD}_{600}\right)$. The cultures were subjected to shake flask fermentation at $200 \mathrm{rpm}$ at either 25 or $30^{\circ} \mathrm{C}$ with subsequent $400 \mu \mathrm{L}$ feeding of appropriate carbon source (glucose or xylose) at $12 \mathrm{~h}$ interval for 4 days. Samples were withdrawn every $12 \mathrm{~h}$ interval to detect extracellular enzyme secretion by subjecting $1 \mathrm{~mL}$ of the sample to centrifugation at 12,000 $\mathrm{g}$ for $5 \mathrm{~min}$, follow by careful separation of the supernatant and the pellet. The fermentation supernatants were thereafter used as sample for determination of extracellular secretion of $\beta$-galactosidase during the fermentation period while the pellets were disrupted by glass beads and used for determination of intracellular synthesis of the enzyme.

\section{Disruption of fungal cell}

Cells were disrupted following the method described by Costa-Silva et al. [14]. Pellet cells from fermentation medium were washed with $0.1 \mathrm{~N}$ saline solution before disruption and cells were disrupted using glass bead technique. The fungal mass was mixed with sterile glass beads $(425-600 \mu \mathrm{M}$, Sigma) and lysis buffer (100 mM Tris $\mathrm{HCl}$ [pH 8.0], $50 \mathrm{mM}$ EDTA, $3 \%$ SDS) before subsequent disruption using a table top homogenizer with intermittent cooling on ice. Ten disruption cycle processes with 1-min disruption and 1-min cooling single cycle were adopted. The beads were separated and the cell homogenates were centrifuged at 6,500 rpm for $15 \mathrm{~min}$ and viewed under light microscope. The lysed homogenates (supernatant) were thereafter evaluated for enzyme synthesis.

\section{$\beta$-galactosidase assay}

$\beta$-galactosidase activity was determined by adding $100 \mu \mathrm{L}$ reaction mixture containing $0.25(\mathrm{w} / \mathrm{v})$ oNPG in $0.1 \mathrm{~mol} / \mathrm{L}$ sodium acetate buffer $(\mathrm{pH} \mathrm{5.2)}$ to $25 \mu \mathrm{L}$ of fermentation supernatant or the lysed homogenate and incubated at $60{ }^{\circ} \mathrm{C}$ for $10 \mathrm{~min}$. $125 \mu \mathrm{L}$ of $1 \mathrm{M} \mathrm{Na}_{2} \mathrm{CO}_{3}$ was added to terminate the reaction. The release of o-nitrophenol (oNP) was measured calorimetrically through the absorbance at $420 \mathrm{~nm}$ and one unit of $\beta$-Galactosidase was defined as the amount of enzyme that releases $1 \mu \mathrm{mol}$ of oNP per min [15]. 


\section{Results and discussion}

\section{Isolation from different sources}

Fungi were isolated from stream and pond water samples. In total, 7 fungal isolates were identified. SB04, SB01, SC02 and SB03 were isolated from stream source while SA01, SC01 and SA02 were isolated from pond water source. The morphological and microscopic features are documented in Table 2. Upon submission of the sequenced data to the GeneBank, 100 and $99 \%$ similarity of KR029081 accession number (a.n.) was obtained for SB01 and SC01, respectively while $99 \%$ KR137638 a.n. was obtained for both SA01 and SC02. This outcome confirmed that SB01 and SC01 were identical to $A$. oryzae, while $\mathrm{SA} 01$ and $\mathrm{SC} 02$ toA. niger.

Table 2 Morphological features of the fungal isolates.

\begin{tabular}{ccccc}
\hline CODING & Conidiophores & Phialides & Vesicles & Tentative organisms \\
\hline SA01 & $\begin{array}{c}\text { Long, smooth and } \\
\text { colourless }\end{array}$ & Biseriate & Round, radiate head & Aspergillus niger \\
\hline SB01 & $\begin{array}{c}\text { Long, smooth and } \\
\text { colourless }\end{array}$ & Biseriate & Round, radiate head & Aspergillus oryzae \\
\hline SB03 & $\begin{array}{c}\text { Short, smooth } \\
\text { colourless }\end{array}$ & Biseriate & Round,radiate head & Penicillium corylophilum \\
\hline SB04 & $\begin{array}{c}\text { Long, smooth } \\
\text { colourless }\end{array}$ & Uniseriate & Huge, clavate-shaped & Aspergillus candids \\
\hline SC01 & Long smooth branched & Uniseriate & Wide clavate-shaped & Aspergillus oryzae \\
\hline SC02 & $\begin{array}{c}\text { Long, smooth and } \\
\text { colourless }\end{array}$ & Biseriate & Round, radiate head & Aspergillus niger \\
\hline
\end{tabular}

Mal-digestion of lactose is the most common disorder of intestinal carbohydrate digestion in human and it is a widespread problem occurring in approximately $70 \%$ of the world population [16]. $\beta$ galactosidase, also known as lactase, hydrolyzes lactose the sugar in milk into its components; glucose and galactose. The wide occurrence and application of this enzyme have made it a model enzyme of most host-secretion studies [17]. Although some proteins such as human serum albumin and antibody fragments can be highly secreted from native host [18]; however, majority of others are still being reported in low level secretion, owing to different bottlenecks such as; mis-folding, sub-optimal conditions and secretion limitation pathways which may result in accumulation of these proteins in the endoplasmic reticulum, among others [19]. Nevertheless, efforts had been directed towards overcoming this bottleneck [20,21], but unfortunately, the sources of these proteins are rarely investigated.

The biodiversity and ecological instability of aquatic environment suggest that microorganisms in this habitat may be good candidates for enzyme screening, and also, proves their tolerance to secretion, thus serving as a guide towards its candidacy for heterologous secretion. To test this hypothesis, $\beta$ galactosidase gene from isolated organisms were amplified by Polymerase Chain Reaction (PCR) using gDNA as template. $\beta$-galactosidase coding genes were successfully amplified from the four fungal isolates. Their appropriate gene sizes 2,900 and 3,000 bp which correspond to the size of this enzyme $[13,22]$, were successfully mapped with the marker size while the negative control revealed no band size (Figure 1). 


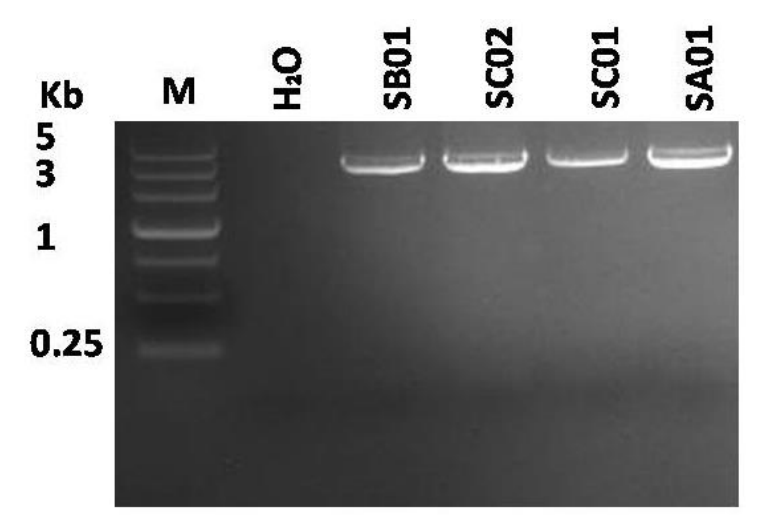

Figure 1 Amplification of $\beta$-galactosidase gene from fungal isolates. SB01 (A. oryzae from stream) SC01 (A. oryzae from pond), SA01 (A. niger from pond) and SC02 (A. niger from stream), M (Marker in kilobase).

For efficient metabolic processes, microorganisms must be subjected to optimal conditions [23]. In view of this, the optimal conditions for the secretion of $\beta$-galactosidase were rationally determined. Temperature is one of the parameters that had been implicated in the efficient secretion of proteins in microbial host factory whose optimization must be applied in order to improve protein secretion. Additionally, secretion is another bottleneck encountered by microbial cell, as studies have indicated that protein misfolding within the intracellular space adversely affects the efficient secretion of proteins irrespective of the efficient synthesis of such protein. Therefore, these factors were considered to optimize $\beta$-galactosidase secretion capability of the isolated organisms. At $25^{\circ} \mathrm{C}$, all the 4 fungal isolates produced certain level of the enzyme. SB01 produced 22.6 and $11.5 \mathrm{U} / \mathrm{mL}$ extracellular and intracellular enzymes respectively, which is the highest activity observed in all the strains examined. In addition to this, all the strains showed gradual increase in enzyme secretion with the lowest secretion obtained in SA01 isolate which produced $13.3 \mathrm{U} / \mathrm{mL}$ extracellular enzyme activity at $72 \mathrm{~h}$ of the culturing processes. SB01 showed a geometric rise in intracellular accumulation of the enzyme while SC02 only showed $3.1 \mathrm{U} / \mathrm{mL}$ intracellular enzyme activity during the culturing processes (Figure 2).
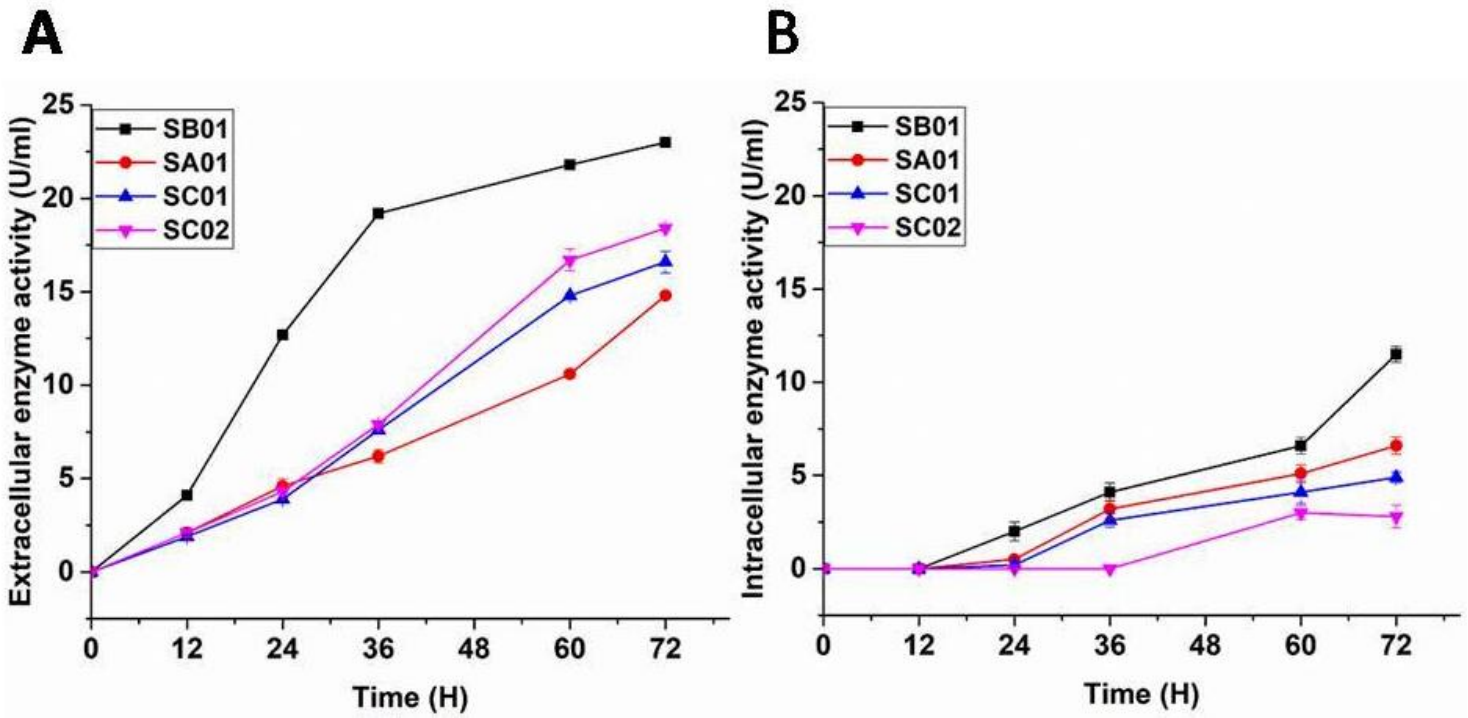

Figure $2 \beta$-galactosidase production at $25^{\circ} \mathrm{C}$; A) Extracellular secretion. B) Intracellular synthesis. SB01 (A. oryzae from stream), SC01 (A. oryzae from pond), SA01 (A. niger from pond) and SC02 (A. niger from stream). Three parallel flasks are tested for each strain. Error bars represent deviations $(\mathrm{n}=3)$. 
At $30{ }^{\circ} \mathrm{C}$, extracellular $\beta$-galactosidase enzymatic activity was considerably lower compared to the $25{ }^{\circ} \mathrm{C}$ and intracellular enzyme secretion at same culturing temperature. For extracellular enzyme secretion, SB01 isolates produced $7.8 \mathrm{U} / \mathrm{mL}$ while SC02 produced $0.6 \mathrm{U} / \mathrm{mL}$. There was also a decline in the $\beta$-galactosidase production in SC01 at $60 \mathrm{~h}$ of the culturing processes (Figure 3A). The intracellular enzyme activity also revealed that SB01 synthesized $15.1 \mathrm{U} / \mathrm{mL}$ at $36 \mathrm{~h}$ culturing processes and upon the extension of the culturing period, the intracellular enzyme synthesis began to decline. SC02 also synthesized minimal enzyme throughout the processes (Figure 3B).

A

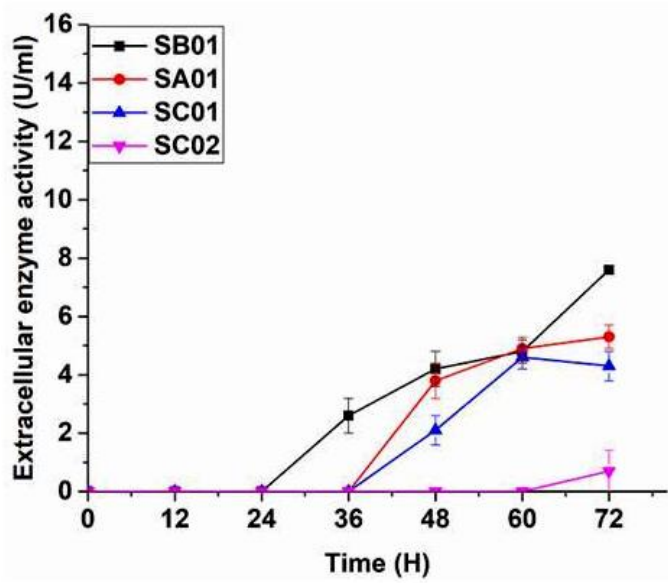

B

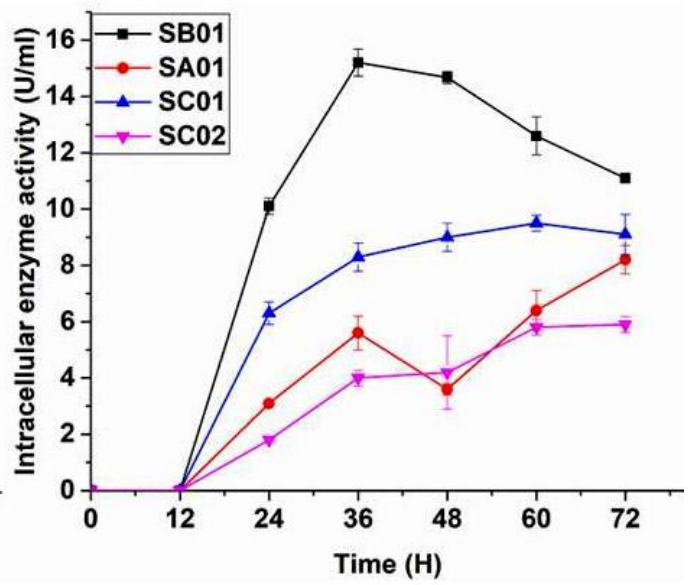

Figure $3 \beta$-galactosidase production at $30{ }^{\circ} \mathrm{C}$; A) Extracellular secretion. B) Intracellular synthesis. SB01 (A. oryzae from stream) SC01 (A. oryzae from pond), SA01 (A. niger from pond) and SC02 (A. niger from stream). Three parallel flasks are tested for each strain. Error bars represent deviations $(\mathrm{n}=3)$.

The observed increase in extracellular $\beta$-galactosidase secretion at $25{ }^{\circ} \mathrm{C}$ compared to $30{ }^{\circ} \mathrm{C}$ suggests that lower temperature favors the regulation pattern of this enzyme and most especially its synthesis within the intracellular space. Dragositis et al. [24], reported that lower temperature efficiently enhanced heterologous protein secretion in Pichia pastoris by attenuating the folding stress responses. Moreover, the observed increase in intracellular synthesis of $\beta$-galactosidase at $30{ }^{\circ} \mathrm{C}$ also suggests that this temperature may affect the key organelles responsible for enzyme processing. More importantly, protein secretion is a very complex process, encompassing multiple steps and thousands of genes [25]. The key gene aiding the intracellular synthesis and accumulation of $\beta$-galactosidase within the intracellular space may be difficult to predict. Eukaryotic cells have developed responses to folding proteins [26] which had been adopted in fungi as a means of alleviating protein misfolding [27]. Therefore, harnessing the potential of this mechanism may reduce $\beta$-galactosidase intracellular accumulation, and hence optimizes its extracellular secretion at $25^{\circ} \mathrm{C}$.

The synthesis of $\beta$-galactosidase by the fungal isolates may also be directly linked to the carbon source which the organism utilized for their metabolic activities. In fact, studies had revealed that supplementation of carbon source could be a panacea for improving protein secretion [28]. In view of this, carbon supplementation was harnessed in downstream processes as a means of improving the enzyme production. Xylose supplementation into the fermentation medium produced $\beta$-galactosidase in proportion varying from those on glucose-based medium, although there was also increase in enzyme production throughout the culturing processes. At $72 \mathrm{~h}$, SB01 produced $11.2 \mathrm{U} / \mathrm{mL}$ while SA01 and SC01 produced approx. $8 \mathrm{U} / \mathrm{mL}$ extracellular enzyme only after $12 \mathrm{~h}$ of the culturing processes (Figure 4A). Contrary to the findings on glucose-based medium, the intracellular enzyme synthesis was higher than the extracellular secretion. Both SB01 and SC02 accumulated 24.3 and $17.7 \mathrm{U} / \mathrm{mL} \beta$-galactosidase respectively at $72 \mathrm{~h}$ (Figure $\mathbf{4 B})$. 

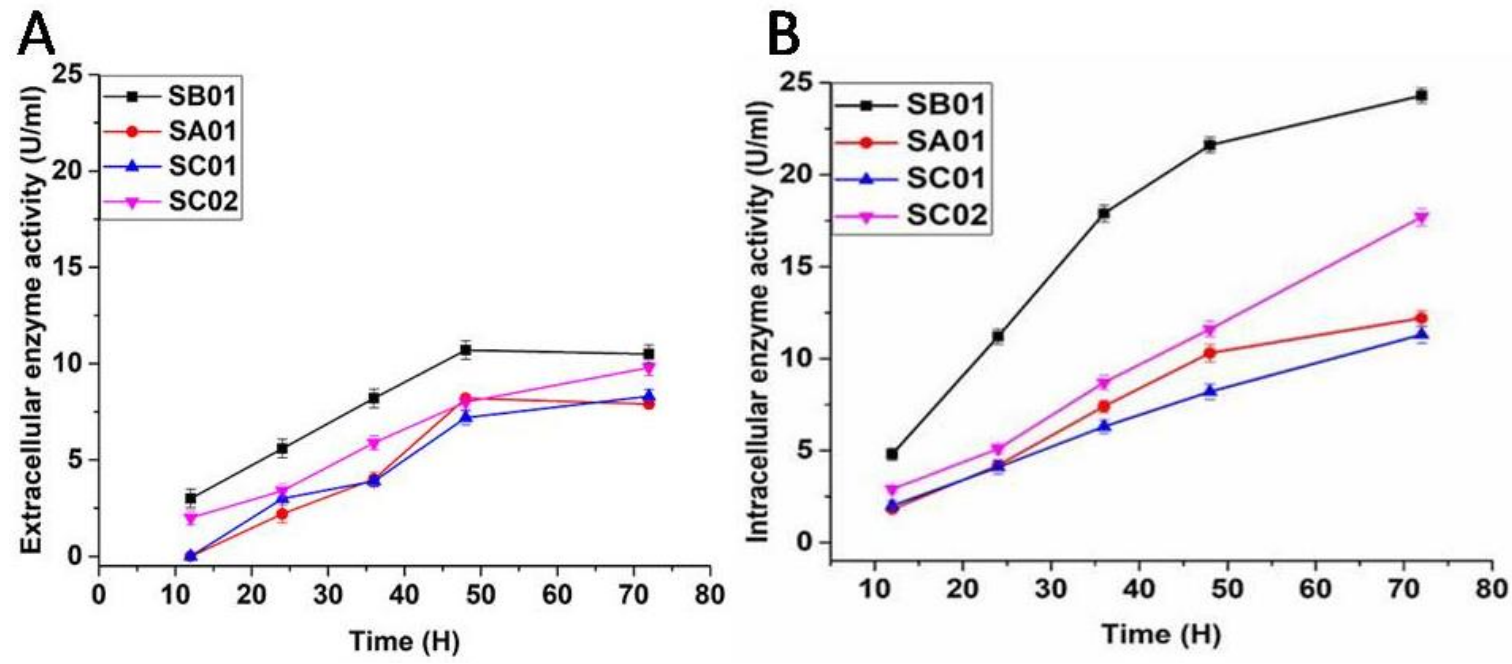

Figure 4 Effect of xylose supplementation on $\beta$-galactosidase activityat $25^{\circ} \mathrm{C}$; A) Extracellular secretion. B) Intracellular synthesis. SB01 (A. oryzae from stream) SC01 (A. oryzae from pond), SA01 (A. niger from pond) and SC02 (A. niger from stream). Three parallel flasks are tested for each strain. Error bars represent deviations $(\mathrm{n}=3)$.

At $30{ }^{\circ} \mathrm{C}$, the extracellular enzyme secretion was significantly lesser than the intracellular synthesis. In all the fungal isolates examined, only SB01 secreted minimal level of $\beta$-galactosidase at $36 \mathrm{~h}$ of the culturing processes. Although other isolates also produced minimal enzyme activity, but towards the end of the fermentation processes (Figure 5A). The intracellular synthesis at this incubation temperature was significantly higher than the extracellular. At $12 \mathrm{~h}$ of the fermentation period all the isolates accumulated certain level of $\beta$-galactosidase enzyme till the end of the fermentation period (Figure 5B).
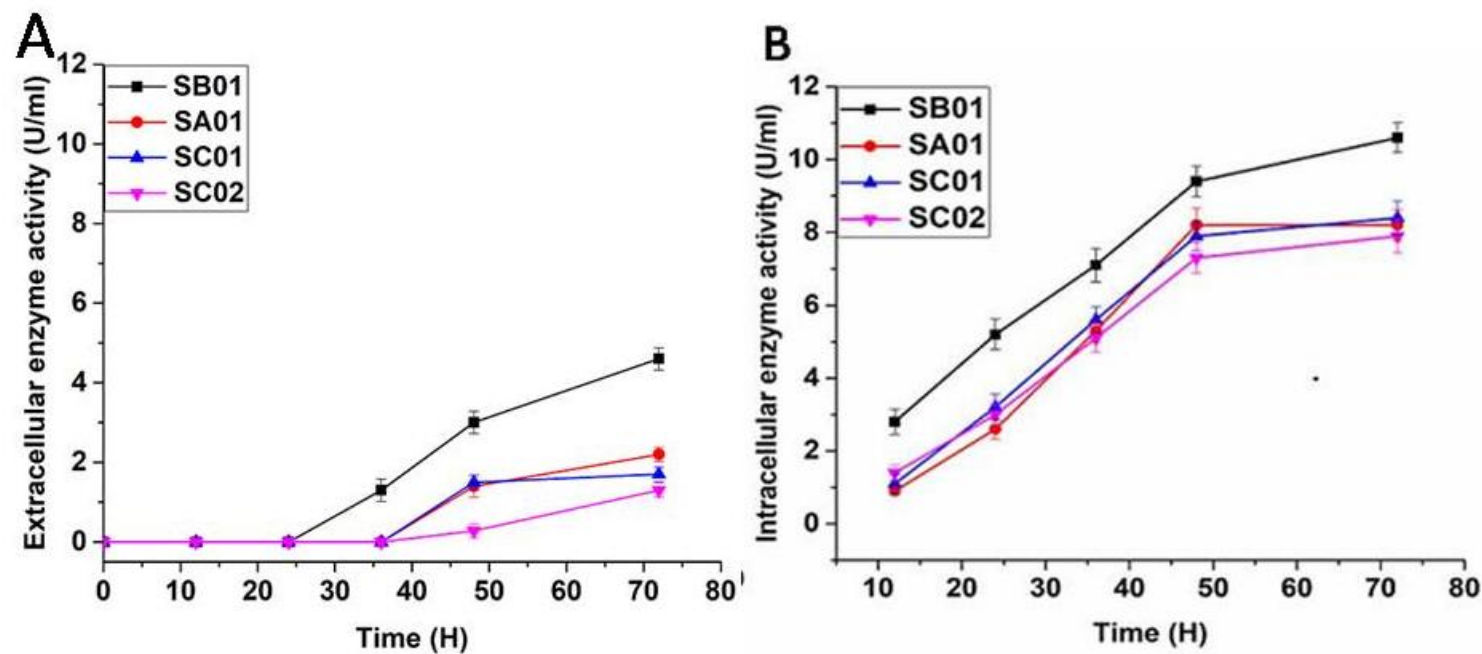

Figure 5 Effect of xylose supplementation on $\beta$-galactosidase activityat $30{ }^{\circ} \mathrm{C}$; A) Extracellular secretion. B) Intracellular synthesis. SB01 (A. oryzae from stream) SC01 (A. oryzae from pond), SA01 (A. niger from pond) and $\mathrm{SC} 02$ (A. niger from stream). Three parallel flasks are tested for each strain. Error bars represent deviations $(\mathrm{n}=3)$.

Studies into the growth pattern and glucose utilization of the substrate revealed that the isolates followed the same pattern in glucose utilization with 3 and $5 \mathrm{~g} / \mathrm{L}$ residual glucose concentrations in SB01 and SA01 as seen in (Figure 6B). Findings into biomass accumulation also revealed similar pattern with 19.1 in SB01 been the highest cell density while other isolates demonstrated insignificant difference in the growth at the end of the fermentation period (Figure 6A). On xylose-based medium, the highest biomass accumulated at $72 \mathrm{~h}$ of the fermentation processes only reached 12.6 at $\mathrm{OD}_{600}$ and the variation 
in growth pattern was insignificant to other isolates (Figure 6C) while the rate of substrate utilization was minimal as indicated by the residual xylose concentration (Figure 6D).
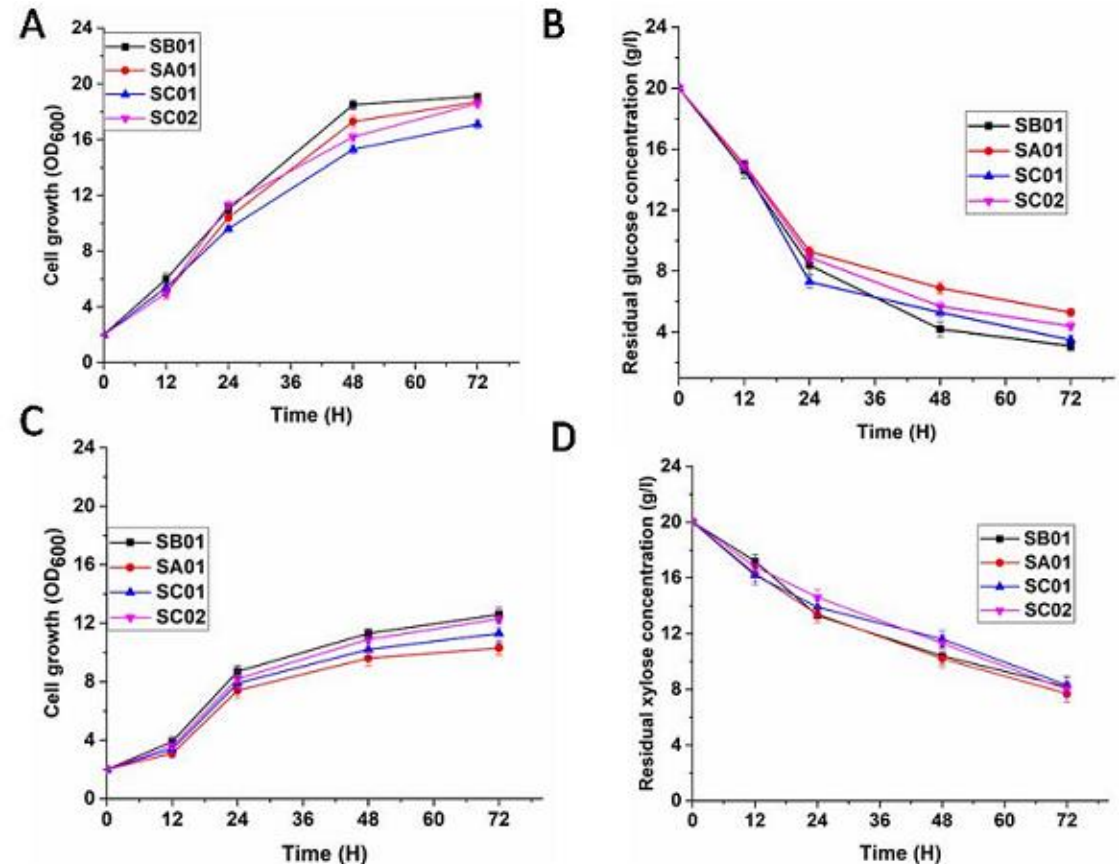

Figure 6 Cell growth and sugar utilization pattern of the isolates isolate; A) Cell growth on glucose based medium, B) Residual glucose concentration, C) Cell growth on xylose based medium, and D) Residual xylose concentration. SB01 (A. oryzae from stream) SC01 (A. oryzae from pond), SA01 (A. niger from pond) and SC02 (A. niger from stream). Three parallel flasks are tested for each strain at $30{ }^{\circ} \mathrm{C}$. Error bars represent deviations $(\mathrm{n}=3)$.

The supremacy of glucose over xylose in extracellular secretion of the enzyme may not be unconnected to the glycolytic pathway that is naturally present in the isolates which converts glucose to the utilizable form for subsequent generation of ATP, and thus aiding the trafficking of this enzyme within intracellular spaces. The study is in line with Sati and Bisht [29], who reported glucose as the most preferred carbon sugar for biomass accumulation. In addition to this, the intracellular synthesis of this enzyme at $25^{\circ} \mathrm{C}$ on xylose supplementation compared well with the glucose counterpart. The reason for this cannot be ascertained but there is prediction that the slow utilization of xylose favors the synthesis of protein secretion but represses the key genes for either extracellular trafficking or for Unfolding Protein Responses which begs for further study.

\section{Conclusion}

This study identified a filamentous fungus from an aquatic body as a promising source for $\beta$ galactosidase secretion, and that downstream optimization can be achieved through glucose optimization for industrial application. The study also revealed that supplementation of xylose can result into intracellular accumulation of the enzyme. Therefore, to alleviate the challenge, investigation into the regulation pattern of key genes that are associated with folding and misfolding of proteins within the cellular compartment during culturing processes is recommended as a means to upstream optimization.

\section{Acknowledgements}

We appreciate the support of Biosolution Laboratory, Akure, Ondo State, Nigeria. 


\section{References}

[1] NA Soliman. Coproduction of thermostable amylase and beta-galactosidase enzymes by Geobacillus stearothermophilus SAB-40: Application of plackett-burman design to evaluate culture requirements affecting enzyme production. J. Microbiol. Biotechnol. 2008; 18, 695-703.

[2] CA Hsu, RC Yu, SL Lee and CC Chou. Cultural condition affecting the growth and production of beta-galactosidase by Bifidobacterium longum CCRC 15708 in a jar fermenter. Int. J. Food Microbiol. 2007; 116, 186-9.

[3] D Todorova-Balvay, I Stoilova, S Gargova and MA Vijayalakshmi. An efficient two step purification and molecular characterization of beta-galactosidases from Aspergillus oryzae. J. Mol. Recognit. 2006; 19, 299-304.

[4] JW Kim and SN Rajagopal. Isolation and characterization of beta-galactosidase from Lactobacillus crispatus. Folia Microbiol. 2000; 45, 29-34.

[5] BR Mohapatra, M Bapuji and A Sree. Production of industrial enzymes (amylase, carboxymethyl cellulaseand protease) by bacteria isolated from marine sedentary organisms. Acta Biotechnol. 2003; 23, 75-84.

[6] PS Panesar, S Kumari and R Panesar. Potential applications of immobilized beta-galactosidase in food processing industries. Enzym. Res. 2010; 2010, 473137.

[7] SC Silvério, EA Macedo, JA Teixeira and LR Rodrigues. New $\beta$-galactosidase producers with potential for prebiotic synthesis. Bioresour. Tech. 2017; 250, 131-9.

[8] A Emimol, G Ganga, R Parvathy, G Radhikan and GM Nair. Screening of microbes producing extracellular hydrolytic enzyme from corporation waste dumping site and house hold waste for the enhancement of bioremediation methods. J. Pharm. Biol. Sci. 2012; 4, 54-60.

[9] A Shade, H Peter, SD Allison, DL Baho, M Berga, H Buirgmann, DH Huber, S Langenheder, JT Lennon, JB Martiny, KL Matulich, TM Schmidt and J Handelsman. Fundamentals of microbial community resistance and resilience. Front. Microbiol. 2012; 3, 417.

[10] JL Green, BJM Brendan and RJ Whitaker. Microbial biogeography: From taxonomy to traits. Science 2008; 320, 5879.

[11] Medical microbiology guide, Available at: https://microbeonline.com/lactophenol-cotton-blue-Ipcbmounts-principle-staining-protocol, accessed November 2019.

[12] J Burik, RW Schreckhise, TC White, RA Bowden and D Myerson. Comparism of six extraction techniques for isolation of DNA from filamentous fungi. Med. Mycol. 1998; 36, 299-303.

[13] H Sun, EO Bankefa, OI Ijeoma, L Miao, T Zhu and Y Li. Systematic assessment of Pichia pastoris system for optimized b-galactosidase production. Synth. Syst. Biotechnol. 2017; 2, 113-20.

[14] TA Cost-Silva, JC Flores-Santos, RKB Freire, M Vitolo and A Pessoa. Microbial cell disruption methods for efficient release of enzyme L-asaparaginase. Prep. Biochem. Biotechnol. 2018; 48, 707 17.

[15] P Katrolia, Q Yan, H Jia, Y Li, Z Jiang and C Song. Molecular cloning and high level expression of a $\beta$-galactosidase gene from Paecilomyces aerugineus in Pichia pastoris. J. Mol. Catal B Enzym. $2011 ; 69,112-9$

[16] RP Heaney. Dairy intake, dietary adequacy and lactose intolerance. Adv. Nutr. 2013; 4, 151-6

[17] M Becerra, E Rodriguez-Belmonte, ME Cerdan and MI González-Siso. Extraction of intracellular proteins from Kluveromyces lactis. Food Tech. Biotechnol. 2001; 39, 135-9.

[18] LM Damasceno, CJ Huang and CA Batt. Protein secretion in Pichia pastoris and advances in protein production. Appl. Microbiol. Biotechnol. 2012; 93, 31-9.

[19] Y Zhou, R Raju, C Alves and A Gilbert. Debottlenecking protein secretion and reducing protein aggregation in the cellular host. Curr. Opin. Biotechnol. 2018; 53, 151-7.

[20] EO Bankefa, M wang, T Zhu and Y Li. Hac1p homologues from higher eukaryotes can improve the secretion of heterologous proteins in the yeast Pichia pastoris. Biotechnol. Lett. 2018; 40, 1149-56.

[21] EO Bankefa, M wang, T Zhu and Y Li. Enhancing the secretion pathway maximizes the effects of mixed feeding strategy for glucose oxidase production in the methylotrophic yeast Pichia pastoris. Bioresour. Bioprocess. 2018; 5, 25.

[22] D Niu, X Tian, NP Mchunu, C Jia, S Singh, X Liu, BA Prior and F Lu. Biochemical characterization of three Aspergillus niger $\beta$-galactosidase. Elec. J. Biotechnol. 2017; 27, 37-43.

[23] HA Akinyele, RAO Gabriel-Ajobiewe, OM Ukhureigbe, AA Adebesin and TL Omotayo. Xylanaseproduction potential of Trichoderma Asperellum NG-T161 and NG-T163 isolated from banana farm soils in South Western Nigeria. Curr. Res. Environ. Appl. Mycol. 2019; 9, 301-12. 
[24] M Dragosits, S Pflugl, S Kurz, E Razzazi-Fazeli, IB Wilson and D Rendic. Recombinant Aspergillus $\beta$-galactosidases as a robust glycomic and biotechnological tool. Appl. Microbiol. Biotechnol. 2014; 98, 3553-67.

[25] A Gilchrist, CE Au, J Hiding, AW Bell, J Fernandez-Rodriguez, S Lesimple, H Nagaya, L Roy, SJ Gosline, M Hallett, J Paiement, RE Kearney, T Nilsson and JJM Bergeron. Quantitative proteomics analysis of the secretory pathway. Cell 2006; 127, 1265-81.

[26] KJ Travers, CK Patil, L Wodicka, DJ Lockhart, JS Weissman and P Walter. Functional and genomic analyses reveal an essential coordination between the unfolded protein response and ERassociated degradation. Cell 2000; 101, 249-58.

[27] M Valkonen M Penttilä andM Saloheimo. Effects of inactivation and constitutive expression of the unfolded-protein response pathway on protein production in the yeast Saccharomyces cerevisiae. Appl. Environ. Microbiol. 2003; 69, 2065-72.

[28] RA Brierley, C Bussineau, R Kosson, A Melton and RS Siegel. Fermentation development of recombinant Pichia pastoris expressing the heterologous gene: Bovine lysozyme. Ann. N. Y. Acad. Sci. 1990; 589, 350-62.

[29] SC Sati and S Bisht. Utilization of various carbon sources for the growth of waterborne conidial fungi. Mycologia 2006; 98, 678-81. 